\title{
Experimental and Analytical Studies on Strengthened Axially Loaded RC Columns
}

\author{
Tejash K PATEL ${ }^{1, *}$, Sanjay R SALLA ${ }^{1}$, Sandip A VASANWALA ${ }^{1}$, \\ Chetankumar D MODHERA ${ }^{1}$, Darshan PATEL ${ }^{2}$ and Purvesh PATEL ${ }^{2}$
}

\author{
${ }^{I}$ Department Civil Engineering, S V National Institute of Technology, Surat, India \\ ${ }^{2}$ Department of Civil Engineering, Merchant Institute of Technology, Mehsana, India
}

('Corresponding author's e-mail: er.tejashpatel@gmail.com)

Received: 6 March 2021, Revised: 9 May 2021, Accepted: 16 May 2021

\begin{abstract}
The strengthening and retrofitting of concrete structures are becoming an essential part of the building and its structures. When the building comes of age, there is a need to increase the structural members' strength, life, and resistivity against unfavorable environmental conditions. In the current scenario, ferrocement composites are used for structural strengthening and rehabilitation. Therefore, an experimental investigation is needed to evaluate the effectiveness of the strengthening on the square and circular reinforced concrete columns by ferrocement and micro concrete materials. The experimental results showed that the ferrocement and micro concrete techniques enhanced the stress-strain behavior and displacement limit of the square and circular RC column. The strengthening circular RC column by micro concrete gives a better performance in stress-strain behavior and displacement limit. In addition, the ferrocement and micro concrete strengthening technique is a promising and economical alternative compared to the other strengthening techniques. Also, test results were compared with ACI and CNR-DT representative load-carrying models to verify each model's reliability and accuracy. Furthermore, the TOPSIS method was adopted to find out the best solution for square and circular columns, and cost analysis was carried out.
\end{abstract}

Keywords: Strengthening, RC Column, Ferrocement, Micro Concrete, Stress-strains, Displacement control

\section{Introduction}

Reinforced concrete (RC) is the predominantly traditional building material used all over the world. The strength of all structural members of older building structure designs from previous design codes has been weakened, including the concrete's ductility due to several factors such as earthquakes, tsunamis, fires, cyclones, floods, durability aspects, and periodic time interval. Moreover, there is an increment in loading due to changes in usage or revision in the design codes. It was not rare to find that some structural members could be deteriorated or even damaged in this way.

The column is one of the most critical structural elements to support the compressive (axial loads) load of frame-structured buildings. The prostration of the building column leads to a building's total failure, as only through that element, which vertical loads are transferred to the ground. These elements significantly stabilize such structures vertically and laterally, especially high-rise buildings. RC columns and piles' primary function is to sustain the vertical gravitational loads from superstructures and transfer them safely to the foundation. In addition to the gravity loads, RC structures are vulnerable to lateral and 
http://wjst.wu.ac.th

seismic loads. Wind loads, as the axially loaded RC members, provide significant resistance against the collapse of the superstructure.

In most cases, the increment of dead and live load, which the structures and their poor technical condition should safely carry, needs some strengthening procedures. The strengthening, repair, and rehabilitation of reinforced concrete $(\mathrm{RC})$ is a complex but necessary process for old building structures [1]. Thus, the deteriorated structural members should be inspected. After the examination or inspection, the deteriorated and damaged structural members should be either strengthened or retrofitted using suitable strengthening techniques. The used materials in strengthening or repair may bring them back to their healthy condition based on strengthening measures.

The current research shows that RC columns' strength and deformation can be enhanced through jacketing techniques. In fact, many studies have shown that RC columns' strength and deformation can be increased through jacket technology over the last 3 to 4 decades. The various materials like reinforced concrete, steel, Ferrocement, and various fiber-reinforced polymers (FRP) are useful for strengthening. Moreover, the RC jacket improves the strength and overall efficiency, and reduces the demand for skilled labor.

The potential use of Ferrocement jackets, in general, has recently attracted attention in developing countries due to the availability of its raw materials. Research suggests that the RC columns strengthening can be done at an effective cost due to its method and ability of an appropriate and desired good confinement. Besides, Ferrocement is an excellent material for jackets. It has exclusive characteristics such as high strength/weight ratio, high stiffness/weight ratio, fatigue resistance, water tightness, durability, ductility, fire, corrosion protection, crack control, and energy absorption [2-7].

For example, Xiong et al. [7] introduced the technique on strengthening the column with ferrocement including steel bars (FS) jackets and noted that the compressive strength, ductility, energy absorption capacity, and displacement capacity of FS commons lums are higher than others [7]. Studies conducted by Kondraivadhan and Pradhan [8] reported that the test results showed that the confined concrete specimens could enhance the ultimate concrete compressive strengths and failure strains. Abdullah et al. [9] extensively studied the column's full length, which increases the column's ductility. Numerous researchers concluded that the repaired reinforced beam and column elements showed the best performance in both service and ultimate loads with Ferrocement jackets [10]. Mourad and Shannag [11] tested the pre-loaded one-third scale RC columns to different fractions of its ultimate load. They found that the strengthening of the pre-loaded RC square columns with ferrocement jackets restored the control columns' initial load-carrying capability. Yaqub et al. [12] measured the effects of ferrocement and fiberreinforced polymer jackets (FRP) to repair post-heated square and circular reinforced concrete columns. They demonstrated that the FRP jacks only increased the compressive strength while ferrocement jackets improved both the column stiffness and strength. Moreover, Soman and Mohan [6] tested the effectiveness of ferrocement jackets on the preloaded square and rectangular RC columns with a fraction of their ultimate load-bearing capacity. Confinement effectiveness and column load capacity increased with some wrapping layers but reduced with an increase in aspect ratio and preload rates.
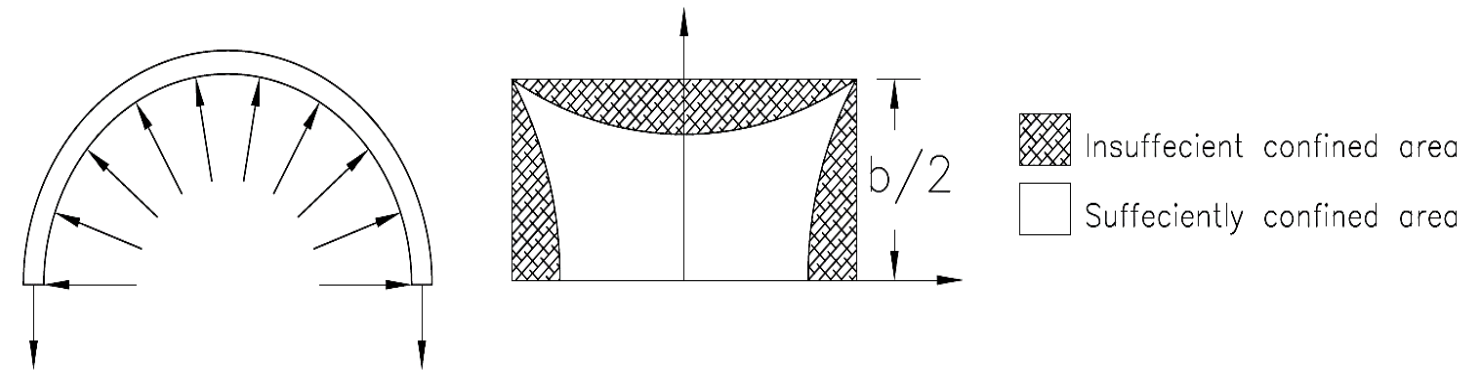

Figure 1 Confinement of jacketed column, circular and square jacketing [2,13]. 
All jacketing techniques strengthen the RC columns square and circular. In circular, RC columns are subjected to axial compression. The concrete core is confined to an outer jacket (Figure 1 [14]) uniformly [4], and the part of the cross-section of the square jacketing is provided with a significant confinement pressure at the corners, as shown in Figure 1.

The behavior of such a uniformly confined concrete core with various containing materials has been thoroughly investigated. In recent years, researchers have also examined the lateral confinement of square columns using various techniques. For instance, the use of ferrocement and micro concrete laminates to repair and strengthen structural elements has been proven to be efficient in providing additional strength and ductility. Besides, such a technique has a significant advantage among others, since it is considered as a low-cost repair technique.

\section{Materials and methods}

\section{Cement and aggregates \& grade of Concrete}

The Ordinary Portland Cement (OPC 53) confirming IS 269: 2015 was used for the experimental work [15]. The fine and coarse aggregate confirming IS 383: 2016 were used as concrete making material. The fine and coarse aggregate properties were checked as per the IS 2386-1963 (Part-I-III) [1618]. The concrete grade was M25, having a mix of (1:1.88:3) and concrete design were carried out as per IS 10262: 2009 [19].

\section{Reinforcement}

In the present study, the Fe 500 was used as reinforcement, and the ultimate tensile strength of 12 and $8 \mathrm{~mm}$ bar was obtained as 587 and $576 \mathrm{MPa}$, respectively. The percentage elongation was 21.66 and $29.25 \%$, respectively, as per IS 1786: 2008 [20].

\section{Welded wire mesh (WWM)}

The locally available welded wire mesh (WWM) was used for the present experimental work. It is necessary to examine its effectiveness because it binds the structural member and the repair material and strengthens the reinforced concrete column. The dimension of WWM in jacketing was $1 \mathrm{~mm}$ diameter wires, and $15 \times 15 \mathrm{~mm}^{2}$ mesh grid size square openings. The testing of WWM was conducted according to ACI standards [21]. The yield strength of WWM was $320 \mathrm{MPa}$.

\section{Ferrocement mortar}

In the Ferrocement mortar mix proportion, the cement and sand ratio was $1: 2$, and the water-cement ratio was kept at 0.5 . The observed compressive strength of the mortar was $31.5 \mathrm{Mpa}$ [22].

\section{Micro concrete mortar}

In the present study, the M50 grade of micro concrete was used. The amount of micro concrete mix used includes cement, ground granulated blast furnace slag (GGBS), silica sand, coarse aggregate (10 mm) water, and water to powder ratio was kept at 0.18 . Micro concrete's compressive strength was conducted as per IS 516: 1959, and the observed value of compressive strength was $72.82 \mathrm{Mpa}$ [22]. The flexural strength was 9.52 MPa, and the test was conducted as per BS 4551: 1998. 
http://wjst.wu.ac.th

Table 1 Details of the test specimen.

\begin{tabular}{|c|c|c|c|c|c|c|c|c|}
\hline \multirow{2}{*}{$\begin{array}{l}\text { Specimen } \\
\text { shapes and } \\
\text { group }\end{array}$} & \multirow[t]{2}{*}{$\begin{array}{l}\text { Specimen } \\
\text { ID }\end{array}$} & \multicolumn{3}{|c|}{$\begin{array}{l}\text { Specimen size excluding } \\
\text { the strengthening }(\mathrm{mm})\end{array}$} & \multicolumn{3}{|c|}{$\begin{array}{l}\text { Specimen size including } \\
\text { the strengthening }(\mathrm{mm})\end{array}$} & \multirow[t]{2}{*}{$\begin{array}{l}\text { Strengthening } \\
\text { materials }\end{array}$} \\
\hline & & Breadth & Width & Height & Breadth & Width & Height & \\
\hline \multirow{5}{*}{$\begin{array}{c}\text { Square } \\
(\text { Group-A ) }\end{array}$} & S 1 & 170 & 170 & 700 & & 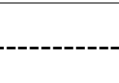 & & $\begin{array}{c}\text { Control } \\
\text { Specimen }\end{array}$ \\
\hline & SF 190 & 170 & 170 & 700 & 190 & 190 & 700 & \multirow{2}{*}{ Ferrocement } \\
\hline & SF 210 & 170 & 170 & 700 & 210 & 210 & 700 & \\
\hline & SM 190 & 170 & 170 & 700 & 190 & 190 & 700 & \multirow{2}{*}{ Micro concrete } \\
\hline & SM 210 & 170 & 170 & 700 & 210 & 210 & 700 & \\
\hline \multirow{5}{*}{$\begin{array}{l}\text { Circular } \\
\text { (Group-B) }\end{array}$} & C 1 & 170 & & 700 & & & & $\begin{array}{c}\text { Control } \\
\text { Specimen }\end{array}$ \\
\hline & CF 190 & 170 & & 700 & 190 & \multirow{4}{*}{-------- } & 700 & \multirow{2}{*}{ Ferrocement } \\
\hline & CF 210 & 170 & & 700 & 210 & & 700 & \\
\hline & CM 190 & 170 & & 700 & 190 & & 700 & \multirow{2}{*}{ Micro concrete } \\
\hline & CM 210 & 170 & & 700 & 210 & & 700 & \\
\hline
\end{tabular}

The entire experimental program was performed and designed to research the effectiveness of 2 potential repair and strengthening strategies for the chipped and damaged square (S) and circular (C) reinforced concrete columns. The stated colors' dimension was $170 \mathrm{~mm}$ diameter for circular and $170 \times 170 \mathrm{~mm}^{2}$ for square, having a height of $700 \mathrm{~mm}$ as per IS 456: 2000 [23]. The ferrocement jackets (F) and micro concrete jackets (M) were used at 2 different thickness, 190 and $210 \mathrm{~mm}$, for repair and strengthening purposes. In this way, a total of 10 columns (5 squares and 5 circular columns) were tested. The design of the square and circular RC columns is as shown in Figure 2.
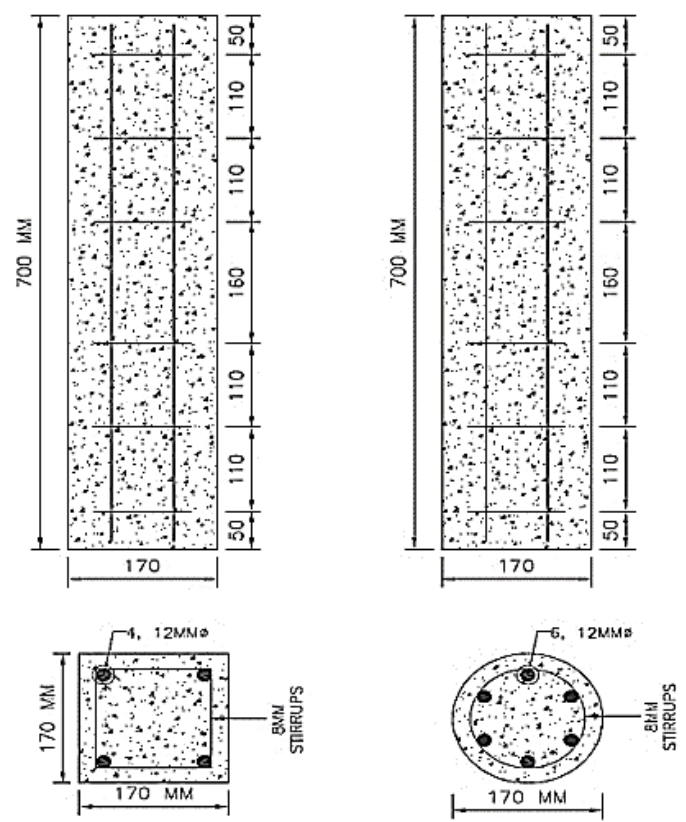

Figure 2 Reinforcement detail of square and circular columns. 


\section{Preparation of test specimens and testing}

The Wooden and PVC molds were used to cast square and cylindrical reinforced concrete column specimens. Moreover, suitable quality materials were used to prevent the formwork's bending and motion during concrete casting. Before concreting, all the molds were oiled first, and the steel cages were prepared and placed in the formwork. A needle vibrator was used after pouring each concrete layer to achieve the concrete's proper compaction during casting time. All samples were cast from the same concrete mix batch to maintain concrete quality. The specimen was water cured for 28 days with the help of gunny bags. Parallelly, the compressive strength test was conducted as per IS 516: 1959 [22] to check the average compressive strength of concrete, and it was observed $29.36 \mathrm{MPa}$ at 28 days.
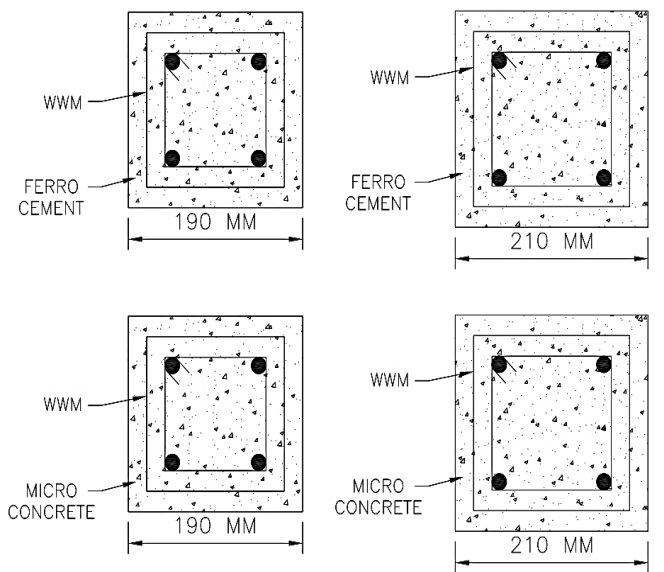
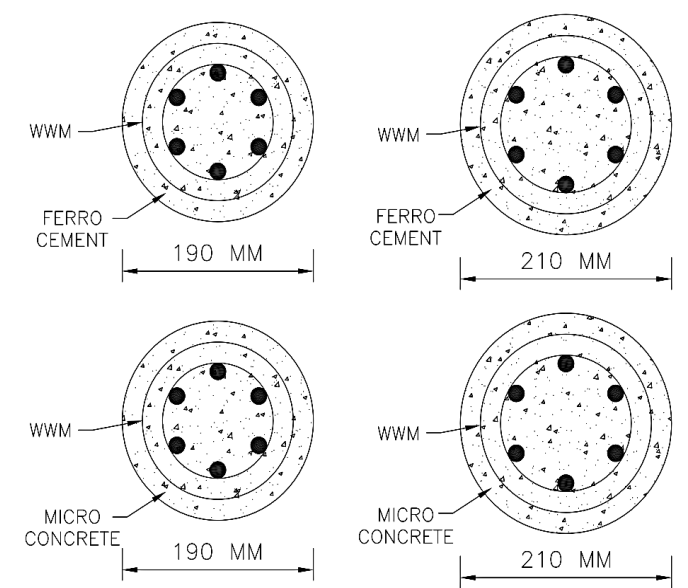

Figure 3 Square and circular column strengthening details.

The RC column specimens were strengthened with ferrocement and micro concrete, as shown in Figure 3 after 28 days of curing. Subsequently, the outer sheath (Cover) of the column specimens was chipped using artificial damage from approximately 25 to $30 \mathrm{~mm}$, and it may help achieve proper bonding. Wire brush and an air blower were used to remove dust from the chipped columns' surface. After all the square and circular column specimens were ready, WWM with ferrocement and micro concrete strengthing was started.

The following steps were involved in the strengthing (Jacketing):

1. A paste of cement, water, and bonding agent (imparting strength to bond between the old and new concrete surfaces) was prepared and applied to the surface with a brush's help.

2. Welded wire mesh was placed at the middle section of the jacket with a clear cover of approximately 10 to $15 \mathrm{~mm}$. The bonding agent was applied, and the mesh was then tied up using binding wires after placing in the formwork.

3. As shown in the figure, the mortar mix was poured around and up to column height specimens, and mold sides were vibrated and compacted by reinforcement bars to ensure maximum mortar penetration around the WWM.

4. A 24-h drying time was allowed to harden the surface. After $24 \mathrm{~h}$, the formwork was removed, and samples of the strengthened column were placed on the wet Gunny Bags surface until testing and placed in a laboratory environment for 14 days.

The curing of the strengthened column was completed. The control column was tested in a loading frame with a capacity of 250 tons. A linear voltage displacement transducer (LVDTs) with a $100 \mathrm{~mm}$ stroke length was installed. LVDT and strain gauge were inlaid on the column surface to measure the displacement and concrete and steel strains, as shown in Figure 4. 
http://wjst.wu.ac.th

A load-controlled actuator with a load cell capacity of 2,500 $\mathrm{kN}$ was used. Capping was provided to ensure that the column ingredients' top and bottom surfaces were uniformly guarded to avert any stress accretion and avoid untimely failures throughout testing. Initially, the column was loaded up to $15 \%$ of their anticipated maximum carrying capacity in the load control mode. Three charging and discharge cycles were carried out for $15 \%$ of his planned peak load to ensure that surface undulation was eliminated from RC column components. The pure axial load protected the load level by up to $15 \%$ of its peak load. All data for load, displacement, and strain measurements of steel and column jacketed surface were obtained by the Data Acquisition System (DAQ).

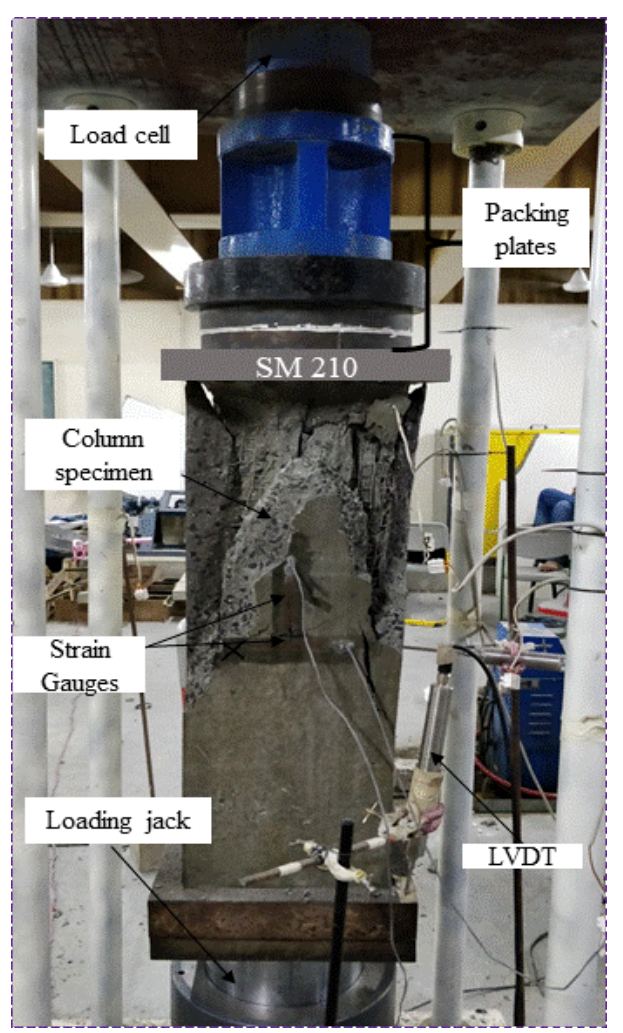

Figure 4 Testing of specimens.

\section{Results and discussions}

\section{Failure modes}

The test results indicated typical compressive failure, with concrete and mortar crushing in all columns. Vertical cracks usually developed close to the column top, where damage was concentrated. Differences in failure modes and crack distribution were caused by the various strengthened materials applied. Figures 5 to 7 show the failure crack pattern of the tested columns. 
http://wjst.wu.ac.th

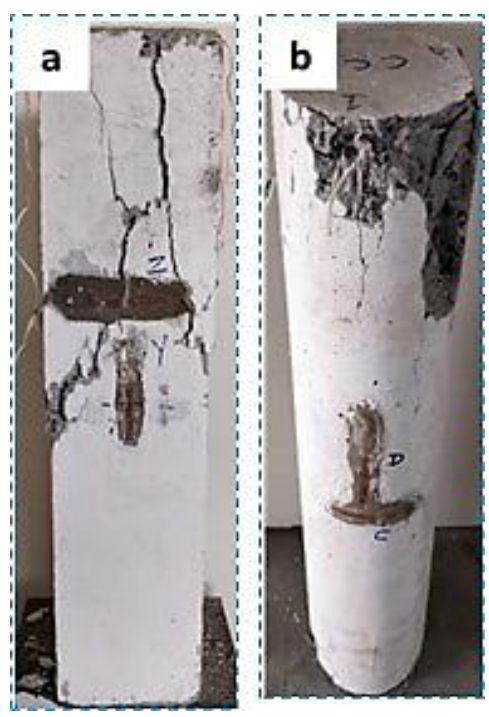

Figure 5 Non-strengthened (a) square RC column (b) circular RC column.

Non-strengthen square and circular RC columns and strengthen square and circular RC columns were examined until ultimate load. In the non-strengthen square RC column specimens, the $1^{\text {st }}$ crack was developed at 45 to $55 \%$ of ultimate load, wherein in the non- strengthen circular RC column specimens, the $1^{\text {st }}$ crack was developed at 40 to $50 \%$ of ultimate load. The observed crack patterns were different in square and circular RC columns. The cracks were observed in a square column at the top to the middle part, wherein the circular column cracks were scattered at the top level, as shown in Figure 5.

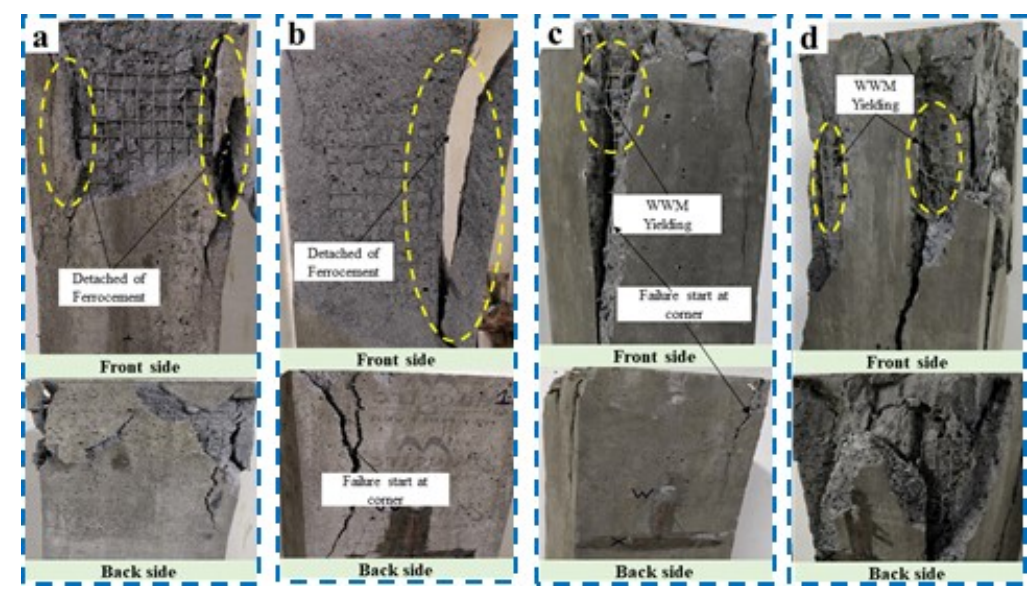

Figure 6 Strengthen square RC columns.

Figure 6 shows the failure pattern in strengthened square $\mathrm{RC}$ columns. The $\mathrm{RC}$ columns strengthened by Ferrocement (SF-190 and SF-210) showed an initial crack at 70 to $75 \%$ of the ultimate load, and strengthened by micro concrete (SM-190 and SM 210) showed an initial crack 80 to $85 \%$ of the ultimate load. RC columns strengthened by Ferrocement showed gradual failures, with uniformly distributed cracks were formed on all sides of the square column specimen. The major cracks were 
http://wjst.wu.ac.th

observed top and the middle part of the specimen, as shown in Figures 6(a) and 6(b). The specimen's failure was started due to Ferrocement layer rupture followed by local debonding with WWM, column of damages after peak load in SF 190 and SF 210. The welded wire mesh failed to grip the actual surface and strengthened the surface.

Additionally, the mortar layers started crumbling when the load reached the ultimate load, as shown in Figures 6(a) and 6(b). RC columns strengthened by micro concrete had sudden failures with explosive sound by bursting concrete, with uniformly distributed cracks formed in all sides square column specimens. The major cracks were observed close to the corner and top part to the middle part, as shown in Figures 6(c) and 6(d). The micro concrete layer rupture occurred severely at the corners in full confined column specimens. The difference between the crushing of concrete coverings indicated that the highest lateral confinement pressure was present at the corners. Additionally, the mortar layers did not detach after the failure, and the corner side of the welded wire mesh (WWM) was yielded, as shown in Figures 6(c) and 6(d).

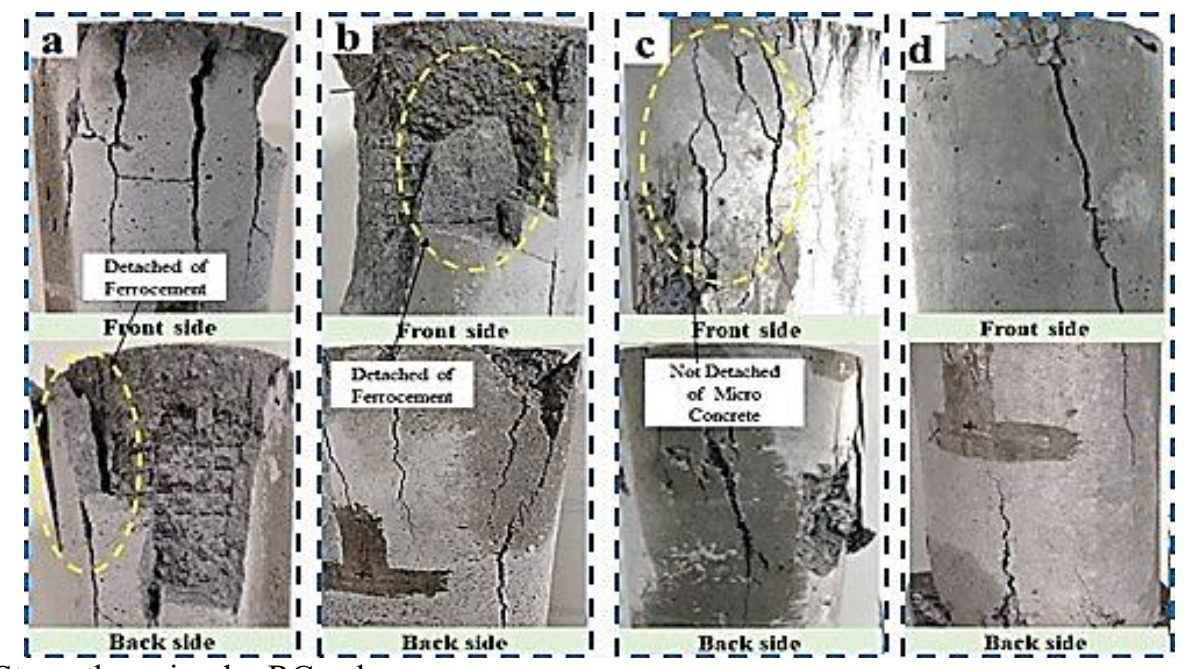

Figure 7 Strengthen circular $\overline{\mathrm{R}} \mathrm{C}$ columns.

Figure 7 shows the failure pattern in strengthen circular RC columns. The RC columns strengthened by Ferrocement (CF-190 and CF-210) showed an initial crack at 70 to $75 \%$ of the ultimate load, and strengthened by micro concrete (CM-190 and CM-210) showed an initial crack 80 to $85 \%$ of the ultimate load. RC columns strengthened by Ferrocement showed gradual failures, with uniformly distributed cracks formed all around the circular column specimen. The major cracks were observed top and the middle part of the specimen, as shown in Figures 7(a) and 7(b). At higher deflection levels, a concrete crack extended from the top and finally rupture the Ferrocement strengthening layers. The welded wire mesh failed to grip the actual surface and strengthened the surface.

Additionally, the mortar layers started crumbling when the load reached the ultimate load, as shown in Figures 7(a) and 7(b). Similarly, RC columns strengthened by micro concrete showed gradual failures, with uniformly distributed cracks formed all around the circular column specimen. Additionally, the mortar layers did not detach after the failure, as shown in Figures 7(c) and 7(d). The overall observations showed that RC columns strengthened by micro concrete gave better load carrying capacity and better displacement control than non-strengthened and strengthened by Ferrocement RC columns, which delayed the RC column's failure. The micro concrete lamina showed cracks, which occurred severely in full confined column specimens. The difference between the not-crushing of concrete coverings indicated that the highest lateral confinement pressure was present in the column. 


\section{Load-displacement behavior}

The relationships between axial load and axial displacements were measured for RC columns with load cell and LVDT. It was observed that both material ferrocement and micro concrete increase the axial load carrying capacity and axial displacement compared to the control columns, as shown following Figures 8 to 11. Figures 8 and 9 shows the relation between axial load and axial displacement for square and circular column.

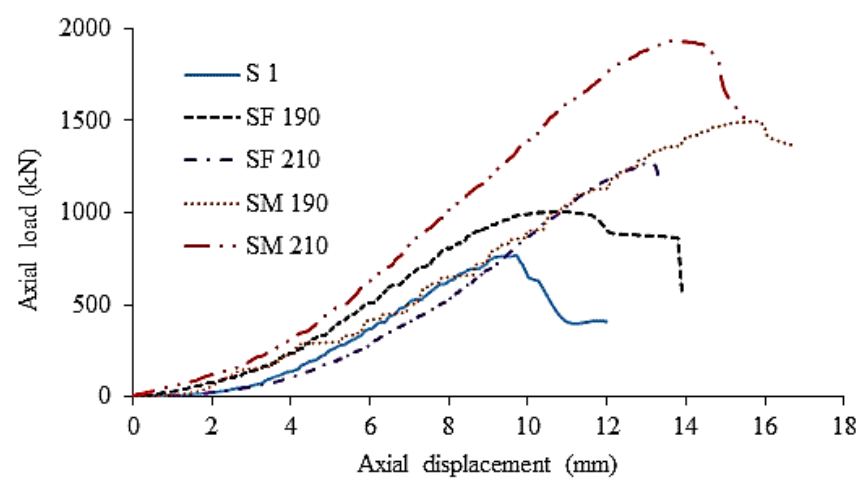

Figure 8 Load-displacement of square columns.

In these experimental works, the ultimate load-carrying capacity and displacement control of micro concrete is more than ferrocement. In fact, it was found that the SM-210 and SF-190 give more control on axial displacement to axial load carrying capacity in micro concrete and ferrocement, respectively Figure 8. It was also found that the SM-210 gives more axial load carrying capacity compared to other column specimens. Moreover, it was observed that the SF-210 column was initially load-carrying less compared to S-1 and SF-190 peak load after sudden failure behaviour in columns, as shown in Figure 8.

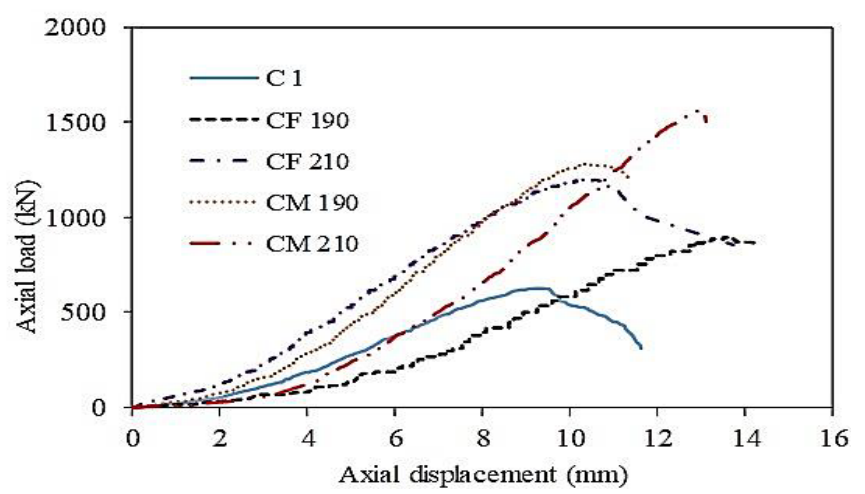

Figure 9 Load-displacement of circular columns.

Similarly, in circular RC columns, CM-190 and CF-210 give more control on axial displacement to axial load carrying capacity in micro concrete and ferrocement, respectively, as shown in Figure 9. It was also found that the SM-210 gives more axial load carrying capacity compared to other column specimens. Moreover, it was observed that the SF-210 column was initially load-carrying less compared to $\mathrm{S}-1$ and SF-190 peak load after sudden failure behaviour in columns, as shown in Figure 8. 
http://wjst.wu.ac.th

Figure 10 shows the percentage of axial load capacity of strengthening square and circular RC columns and compares it with non-strengthen RC columns. In these experimental works, RC columns' ultimate load-carrying capacity strengthened by micro concrete is more than RC columns strengthened by ferrocement. It was also found that the SF-210 and SM-210 give more load-carrying capacity in micro concrete and ferrocement, respectively. The circular RC column has less load-carrying capacity than the square because the available loading area is less than the square RC columns. In circular RC columns, CM-210 and CF-210 give more load-carrying capacity in micro concrete and ferrocement, respectively, as shown in Figure 10. The ultimate load-carrying capacity of SM-190 and CM-190 is higher compared to SF-210 and CF-210. Moreover, CM-190 and CF-210 are higher compared to SM-190 and SF-210, the ultimate load-carrying capacity.

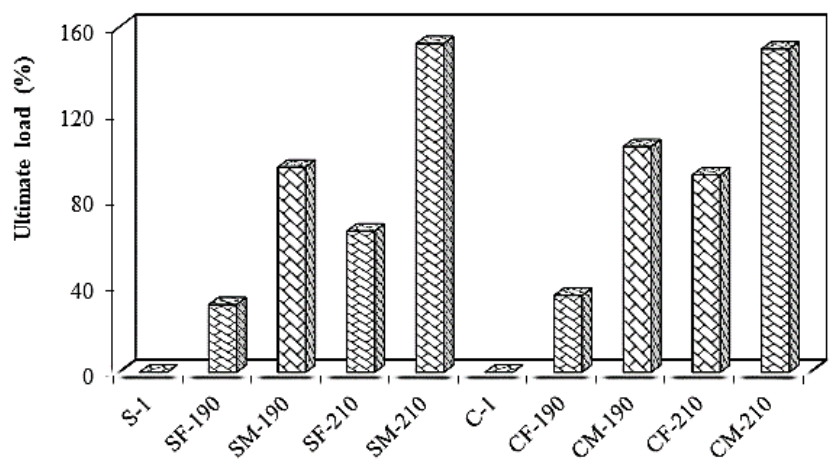

Figure 10 Ultimate load in percentage.

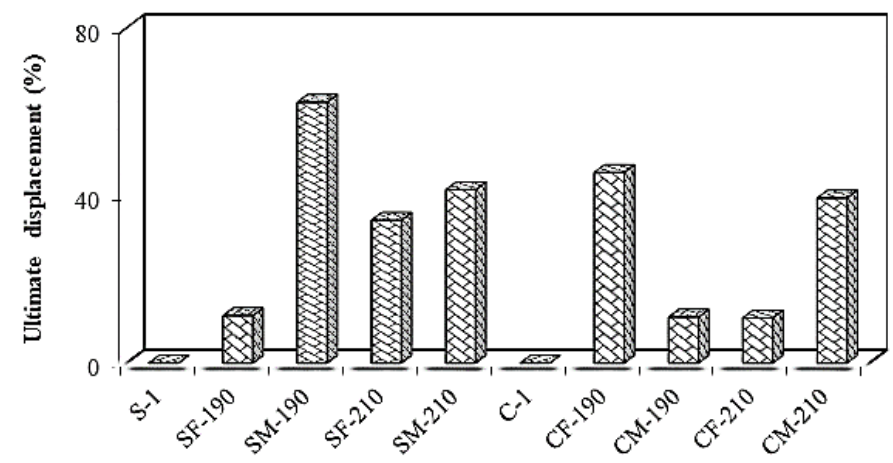

Figure 11 Ultimate displacement in percentage.

Figure 11 shows the percentage of axial displacement of the strengthened square and circular RC columns and compares them with non-strengthen RC columns. In these experimental works, axial displacement of $\mathrm{RC}$ columns strengthened by micro concrete is less compared to $\mathrm{RC}$ columns strengthened by ferrocement. It was also found that the SM-210 and SF-190 give less axial displacement in micro concrete and ferrocement, respectively. Similarly, in circular RC columns, CM-190 and CF-210 give less axial displacement in micro concrete and ferrocement, respectively, as shown in Figure 11. The displacement carrying capacity of SM-190 is higher compared to other column specimens. In addition, the displacement control in CM-190 is higher compared to other column specimens with respect to the load-carrying capacity of the column specimens. 


\section{Strain behavior}

RC Column specimens are divided into 2 groups (Square and Circular) to understand the strain behavior of different materials Ferrocement and Micro concrete and reinforcement behavior. The stressstrain behavior of strengthened and non-strengthened are presented with the help of Figures 12 to $\mathbf{1 5}$. The strain gauge was placed on the column surface at the mid-height of the specimen. The axial strain of concrete was taken as a positive sign, and the lateral strain was taken as a negative sign. Similarly, the axial and transverse strain gauges were placed on the longitudinal reinforcement and stirrups.

Figures 12 and 13 compare the stress Vs. Axial and lateral strain curves of the concrete, withs stress-strains measured on the non-strengthen and strengthen square and circular RC columns. The behavior of axial and lateral strains in the nearer to the linear elastic stage, concrete fails quickly after the plastic stage occurs.

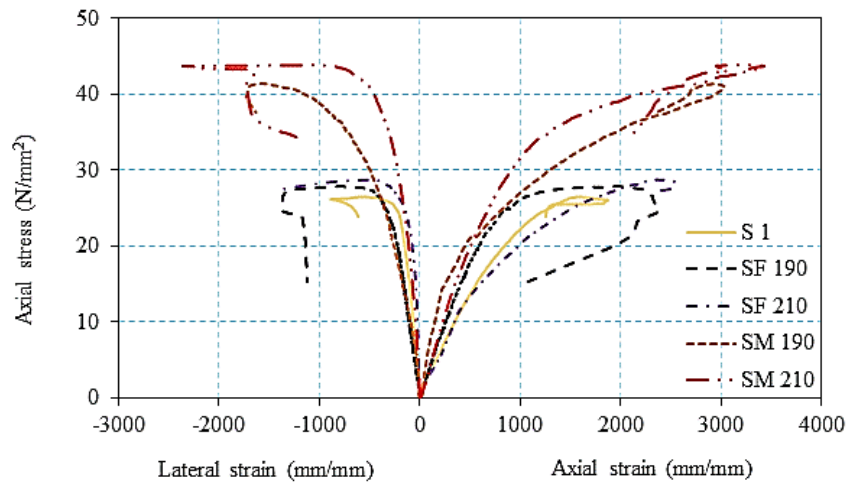

Figure 12 Stress Vs. strains in the concrete of square columns.

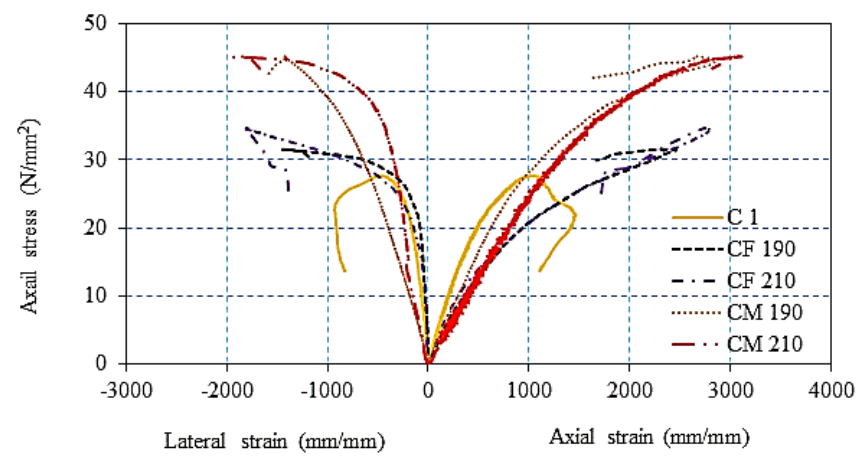

Figure 13 Stress Vs. strains in the concrete of circular columns.

The square and circular RC columns strengthened by Ferrocement mortar showed resembling behavior against the axial and lateral strains in the elastic stage like the non-strengthen column. Figure 12 (SF-190 and SF-210) and Figure 13 (CF-190 and CF-210) show the behavior of the axial and lateral strains in the Ferrocement mortar layer, which fails gradually after the plastic stage occurs. Interestingly, the square and circular RC columns strengthened by Ferrocement mortar do not have any remarkable change exhibited in stress, but axial and lateral strains slightly increase. It leads to failure, which was severely delayed. Moreover, the strengthening of the square and circular RC columns by micro concrete shows the axial and lateral strains' behavior in the elastic and plastic stage like the other columns. Figure 12 (SM-190 and SM-210) Figure 13 (CF-190 and CF-210) shows the axial and lateral strains' behavior in the micro concrete mortar layer fails immediately after the plastic stage occurs. It is noted that drastic 
http://wjst.wu.ac.th

changes in axial and lateral strains were observed and increased so that when failure occurred, it would be delayed significantly.

The above interesting findings indicated that the square and circular columns strengthened by micro concrete mortar showed an increase in the axial strain and lateral strain. In the $2^{\text {nd }}$ stage (plastic stage) of the curve, the non-strengthen and strengthened by Ferrocement square and circular RC column were compared so that the load-carrying capacity increases and the failure occur would be significantly delayed as shown in Figures 12 and 13.

The strain was recorded in both longitudinal and transverse reinforcement bars, as shown in Figures 14 and 15 against the axial load. The strain variation indicates the micro concrete contribution to stress resistance strengthening compared to Ferrocement strengthening. The strengthening of micro concrete has also increased nearly one and a half to twice as much axial strain as the non-strengthen RC column. Moreover, the buckling in micro concrete and Ferrocement strengthening was delayed, and the strain values in the longitudinal reinforcement increased in cases of failure. The Ferrocement and micro concrete strengthening technique helped reduce the overall strain in the steel reinforcement due to the simultaneous contribution, thereby improving the RC column element's overall performance.

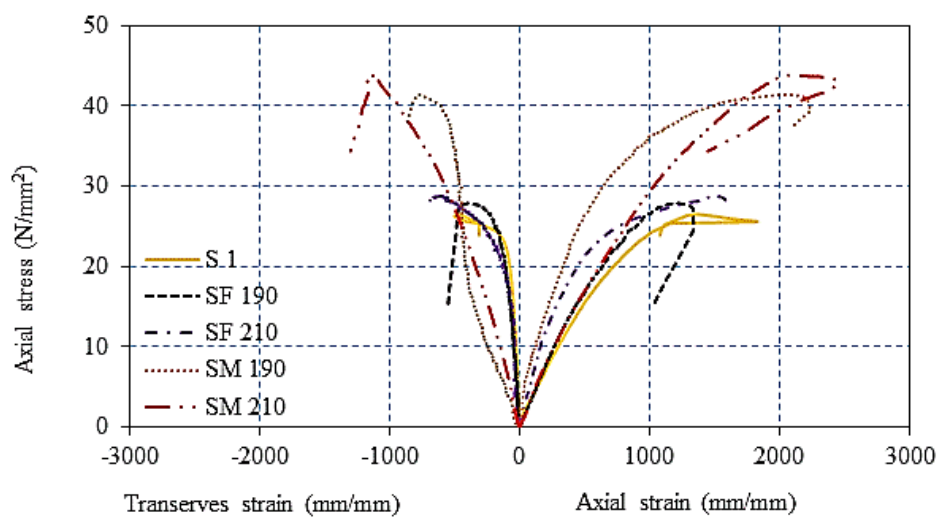

Figure 14 Stress Vs. strains in the steel of square columns.

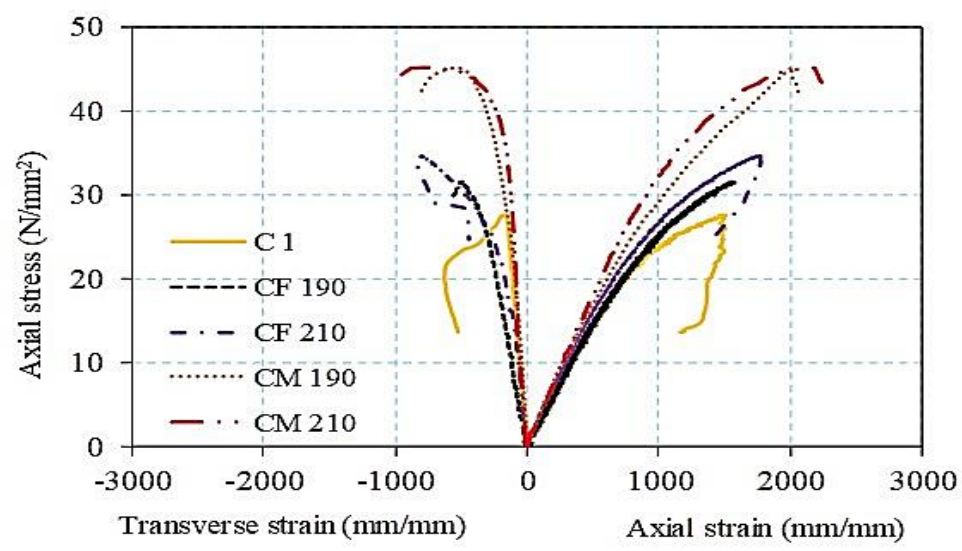

Figure 15 Stress Vs. strains in the steel of circular columns. 
http://wjst.wu.ac.th

\section{Stress behavior}

Figure 16 shows the percentage of the strengthened square and circular RC columns' axial stress capacity compared with non-strengthen RC columns. In this experimental works, the ultimate stress carrying capacity of RC columns strengthen by micro concrete is more compare to RC columns strengthened by ferrocement. It was also found that the SM-190 and SM-210 give more stress carrying capacity in micro concrete square RC columns. In circular RC columns, CM-190 and CM-210 give more stress carrying capacity in micro concrete than ferrocement, as shown in Figure 16.

The circular RC column available loading area is less when compared to the square RC columns with stress-carrying capacity with almost has the same micro concrete strengthening. Though the loading area of circular RC columns is less than square RC columns, there was not much difference in stress carrying capacity. Ferrocement strengthened circular RC columns in stress carrying capacity compared to Ferrocement strengthened square RC columns.

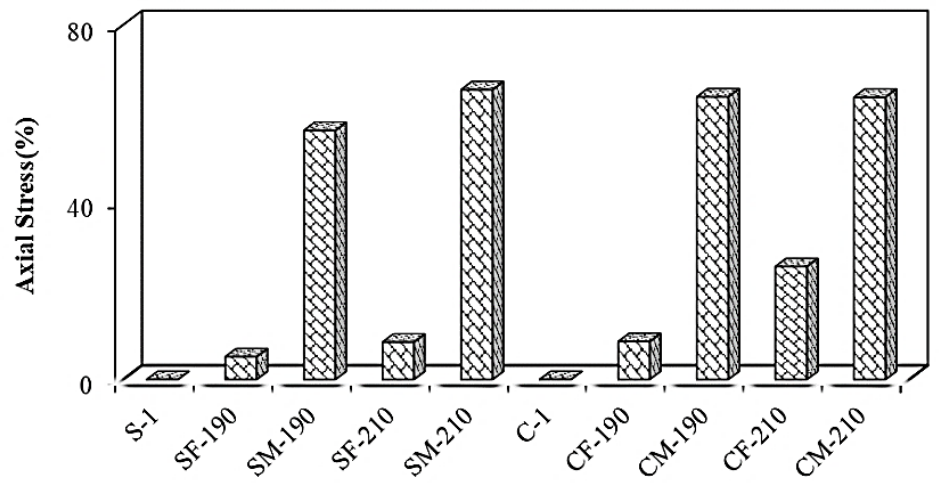

Figure 16 Axial stress in percentage.

\section{Comparison between experimental v/s theoretical axial load}

A detailed analysis of how to determine the strength, strengthening axially loaded square and circular RC columns using ACI-440-2R-08 [14] and CNR-DT-R1-2013[24] guidelines is provided. The ultimate axial load carrying capacity comparison of experimental and theoretical results is shown in the figure. The strengthened square and circular columns ultimate load matches closely with ACI-4402R-08 [14] results. The experimentally and theoretically ACI-440-2R-08 [14] results are nearest because they consider all properties of materials and specimens. Theoretically, CNR-DT-R1-2013 [24] results are in a large difference because this guideline considers a minimum materials properties.

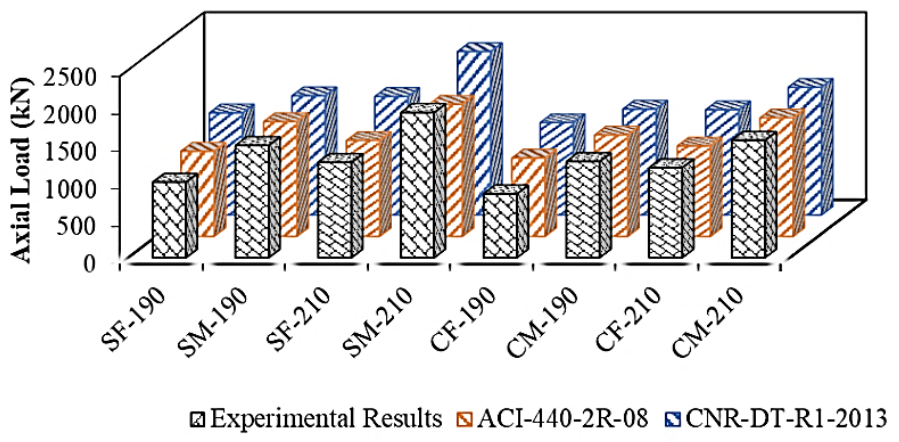

Figure 17 Comparisons of axial load for strengthening columns. 


\section{Cost analysis}

The strengthening of any column should help the economy because the cost analysis had been carried out for the column's actual size and compared with all alternatives. The labor rate, formwork, and materials like Ferrocement, micro concrete, and welded wire mesh were adopted from the locally available market. The cost analysis for strengthening square $\left(230 \times 230 \times 3,000 \mathrm{~mm}^{3}\right)$ and circular $(230 \mathrm{~mm}$ Dia. and 3,000 mm height) column is shown in Tables 2 and 3.

Table 2 Cost analysis for square column.

\begin{tabular}{|c|c|c|c|c|c|c|c|}
\hline \multirow{2}{*}{ Cost Analysis } & \multicolumn{2}{|c|}{ Quantity of Material } & \multirow{2}{*}{ Rate } & \multirow{2}{*}{ SF-240 } & \multirow{2}{*}{ SM-240 } & \multirow{2}{*}{ SF-250 } & \multirow{2}{*}{ SM-250 } \\
\hline & 240 & 250 & & & & & \\
\hline Labor (Nos.) & 3 & 3 & 400.00 & $1,200.00$ & $1,200.00$ & $1,200.00$ & $1,200.00$ \\
\hline Formwork* & 3.08 & 3.20 & 675.00 & $2,079.00$ & $2,079.00$ & $2,160.00$ & $2,160.00$ \\
\hline Wire mesh\# & 2.60 & 2.80 & 165.00 & 429.00 & 429.00 & 462.00 & 462.00 \\
\hline Ferrocement* & 0.096 & 0.123 & $29,000.00$ & $2,784.00$ & - & 3567.00 & - \\
\hline \multirow[t]{2}{*}{ Micro concrete* } & 0.096 & 0.123 & $17,000.00$ & - & 1632.00 & - & $2,091.00$ \\
\hline & & & Total & $6,460.13$ & $5,339.23$ & $7,348.16$ & $6,492.00$ \\
\hline
\end{tabular}

*Calculated in cubic meter \#calculated in a square meter.

Table 3 Cost analysis for circular column.

\begin{tabular}{|c|c|c|c|c|c|c|c|}
\hline \multirow{2}{*}{ Cost Analysis } & \multicolumn{2}{|c|}{ Quantity of Material } & \multirow{2}{*}{ Rate } & \multirow{2}{*}{ CF-240 } & \multirow{2}{*}{ CM-240 } & \multirow{2}{*}{ CF-250 } & \multirow{2}{*}{ CM-250 } \\
\hline & 240 & 250 & & & & & \\
\hline Labor (Nos.) & 3 & 3 & 400.00 & $1,200.00$ & $1,200.00$ & $1,200.00$ & $1,200.00$ \\
\hline Formwork* & 3.20 & 3.20 & 445.00 & $1,424.00$ & $1,424.00$ & $1,472.00$ & $1,472.00$ \\
\hline Wire mesh\# & 2.26 & 2.36 & 165.00 & 372.90 & 372.90 & 389.40 & 389.40 \\
\hline Ferrocement* & 0.080 & 0.090 & $29,000.00$ & $2,320.00$ & - & 2610.00 & - \\
\hline \multirow[t]{2}{*}{ Micro concrete* } & 0.080 & 0.090 & $17,000.00$ & - & $1,360.00$ & - & $1,530.00$ \\
\hline & & & Total & $5,290.34$ & $4,356.26$ & $5,641.52$ & $5,316.90$ \\
\hline
\end{tabular}

*Calculated in cubic meter \#calculated in a square meter.

\section{Analytical analysis}

The experimental result showed that the strengthing by micro concrete is more effective compared to ferrocement. The technique for order performance by similarity to ideal solution (TOPSIS) was used to determine the best alternative among all strengthened columns, which was discussed elsewhere [25]. TOPSIS gives a solution based on the best ideal solution and the worst ideal solution and weightage of attributes calculated by the entropy method [25]. The selected attributes and their weights are shown in the following Table 4. The following Tables 5 and $\mathbf{6}$ gives the weighted normalized matrix. A positive and negative ideal solution was shown in Tables 7 and $\mathbf{8}$, and the calculated performance factor was shown in Tables 9 and $\mathbf{1 0}$. 
http://wjst.wu.ac.th

Table 4 Selected attribute and their weightage by entropy method.

\begin{tabular}{|c|c|c|}
\hline \multicolumn{2}{|l|}{ Attribute } & Justification \\
\hline \multicolumn{2}{|c|}{ Ultimate Load (0.14) } & $\begin{array}{l}\text { To determine the axially load-bearing capacity /axially compressive } \\
\text { strength of column specimen. }\end{array}$ \\
\hline \multicolumn{2}{|c|}{ Ultimate Deflection (0.13) } & To determine bulging and compression in column specimen(mm) \\
\hline \multicolumn{2}{|l|}{ Stress (0.12) } & Investigate compressive/ultimate failure stress in column specimens. \\
\hline \multirow{2}{*}{$\begin{array}{l}\text { Concrete } \\
\text { Strain }\end{array}$} & Linear (0.12) & To identify the behavior of concrete in compression. \\
\hline & $\begin{array}{l}\text { Lateral } \\
(\mathbf{0 . 1 1})\end{array}$ & To identify the behavior of concrete in tension. \\
\hline \multirow[b]{2}{*}{ Steel Strain } & Linear (0.12) & For analyzing longitudinal reinforcement in axial compression \\
\hline & $\begin{array}{l}\text { Transverse } \\
(0.13)\end{array}$ & $\begin{array}{l}\text { For analyzing transverse reinforcement in axially confined tension } \\
\text { capacity }\end{array}$ \\
\hline \multicolumn{2}{|l|}{ Cost (0.13) } & for parsing of economic criteria \\
\hline
\end{tabular}

Table 5 Weightage normalized matrix for square columns.

\begin{tabular}{|c|c|c|c|c|c|c|c|c|}
\hline \multirow{2}{*}{ Samples } & \multirow{2}{*}{$\begin{array}{l}\text { Ultimate } \\
\text { Load }\end{array}$} & \multirow{2}{*}{$\begin{array}{c}\text { Ultimate } \\
\text { Deflection }\end{array}$} & \multirow{2}{*}{ Stress } & \multicolumn{2}{|c|}{ Concrete Strain } & \multicolumn{2}{|c|}{ Steel Strain } & \multirow{2}{*}{ Cost } \\
\hline & & & & Linear & Lateral & Linear & Transverse & \\
\hline SF 190 & & & & 0.0435 & -0.0393 & 0.0420 & & 0.0661 \\
\hline SM 190 & 0.0694 & 0.0756 & 0.0704 & 0.0677 & -0.0790 & 0.0700 & -0.0658 & 0.0547 \\
\hline SF 210 & 0.0588 & 0.0625 & 0.0489 & 0.0543 & -0.0245 & 0.0522 & -0.0520 & 0.0752 \\
\hline SM 210 & 0.0897 & 0.0659 & 0.0746 & 0.0755 & -0.0562 & 0.0725 & -0.0952 & 0.0605 \\
\hline
\end{tabular}

Table 6 Weightage normalized matrix for circular columns.

\begin{tabular}{|c|c|c|c|c|c|c|c|c|}
\hline \multirow{2}{*}{ Samples } & \multirow{2}{*}{$\begin{array}{l}\text { Ultimate } \\
\text { Load }\end{array}$} & \multirow{2}{*}{$\begin{array}{c}\text { Ultimate } \\
\text { Deflection }\end{array}$} & \multirow{2}{*}{ Stress } & \multicolumn{2}{|c|}{ Concrete Strain } & \multicolumn{2}{|c|}{ Steel Strain } & \multirow{2}{*}{ Cost } \\
\hline & & & & Linear & Lateral & Linear & Transverse & \\
\hline CF 190 & 0.0462 & 0.0735 & 0.0469 & 0.0540 & -0.0467 & 0.0496 & -0.0498 & 0.0684 \\
\hline CM 190 & 0.0697 & 0.0561 & 0.0708 & 0.0601 & -0.0464 & 0.0667 & -0.0541 & 0.0563 \\
\hline CF 210 & 0.0653 & 0.0560 & 0.0543 & 0.0620 & -0.0591 & 0.0558 & -0.0790 & 0.0729 \\
\hline CM 210 & 0.0851 & 0.0704 & 0.0708 & 0.0690 & -0.0610 & 0.0680 & -0.0745 & 0.0593 \\
\hline
\end{tabular}


Table 7 Positive and negative ideal solution for square columns.

\begin{tabular}{|c|c|c|c|c|c|c|c|c|}
\hline \multirow{2}{*}{ Samples } & \multirow{2}{*}{$\begin{array}{l}\text { Ultimate } \\
\text { Load }\end{array}$} & \multirow{2}{*}{$\begin{array}{c}\text { Ultimate } \\
\text { Deflection }\end{array}$} & \multirow{2}{*}{ Stress } & \multicolumn{2}{|c|}{ Concrete Strain } & \multicolumn{2}{|c|}{ Steel Strain } & \multirow{2}{*}{ Cost } \\
\hline & & & & Linear & Lateral & Linear & Transverse & \\
\hline $\mathbf{V}+$ & 0.0897 & 0.0519 & 0.0746 & 0.0755 & -0.0790 & 0.0725 & -0.0952 & 0.0547 \\
\hline $\mathbf{V}-$ & 0.0467 & 0.0756 & 0.0474 & 0.0435 & -0.0245 & 0.0420 & -0.0332 & 0.0752 \\
\hline \multicolumn{9}{|c|}{ and negative ideal solution for circular columns. } \\
\hline \multirow{2}{*}{ Samples } & \multirow{2}{*}{$\begin{array}{l}\text { Ultimate } \\
\text { Load }\end{array}$} & \multirow{2}{*}{$\begin{array}{c}\text { Ultimate } \\
\text { Deflection }\end{array}$} & \multirow{2}{*}{ Stress } & \multicolumn{2}{|c|}{ Concrete Strain } & \multicolumn{2}{|c|}{ Steel Strain } & \\
\hline & & & & Linear & Lateral & Linear & Transverse & Co \\
\hline $\mathbf{V}+$ & 0.0851 & 0.0560 & 0.0708 & 0.0690 & -0.0610 & 0.0680 & -0.0790 & 0.0563 \\
\hline $\mathbf{V}-$ & 0.0462 & 0.0735 & 0.0469 & 0.0540 & -0.0464 & 0.0496 & -0.0498 & 0.0729 \\
\hline
\end{tabular}

Table 11 Calculation of performance factor for square columns.

\begin{tabular}{ccccc}
\hline & $\mathbf{S}_{\mathbf{i}}^{+}$ & $\mathbf{S}_{\mathbf{i}}^{-}$ & $\mathbf{P F}_{\mathbf{i}}$ & Ranking \\
\hline SF 190 & 0.1005 & 0.0294 & 0.2260 & $\mathbf{4}$ \\
SM 190 & 0.0439 & 0.0829 & 0.6540 & $\mathbf{2}$ \\
SF 210 & 0.0886 & 0.0300 & 0.2529 & $\mathbf{3}$ \\
SM 210 & 0.0274 & 0.0985 & 0.7823 & $\mathbf{1}$ \\
\hline
\end{tabular}

Table 12 Calculation of performance factor for circular columns.

\begin{tabular}{ccccc}
\hline & $\mathbf{S}_{\mathbf{i}}{ }^{+}$ & $\mathbf{S}_{\mathbf{i}}^{-}$ & $\mathbf{P}_{\mathbf{i}}$ & Ranking \\
\hline CF 190 & 0.0645 & 0.0046 & 0.0660 & $\mathbf{4}$ \\
CM 190 & 0.0340 & 0.0453 & 0.5714 & $\mathbf{2}$ \\
CF 210 & 0.0339 & 0.0429 & 0.5585 & $\mathbf{3}$ \\
CM 210 & 0.0154 & 0.0605 & 0.7971 & $\mathbf{1}$ \\
\hline
\end{tabular}

\section{Conclusions}

The strengthening technique's effectiveness in improving short RC square columns' performance in strength, load-carrying capacity, and ductility was explored through experimental studies. The following major conclusions can be drawn based on the results presented in this study:

1. RC columns strengthened by Ferrocement showed gradual failures, with uniformly distributed cracks formed on all sides of the square and circular column specimen.

2. RC columns strengthened by micro concrete gave sudden failures with explosive sound by bursting concrete, with uniformly distributed cracks formed in all sides' square column specimens.

3. RC columns strengthened by micro concrete showed gradual failures, with uniformly distributed cracks formed all around the circular column specimen.

4. SM-210 and SF-190 gave more control on axial displacement regarding axial load carrying capacity in micro concrete and Ferrocement. CM-190 and CF-210 gave more control on axial displacement to axial load carrying capacity in micro concrete and Ferrocement.

5. SM-210 and SF-210 gave more load-carrying capacity in micro concrete, and ferrocement and CM-210 and CF-210 gave more load-carrying capacity in micro concrete and ferrocement. 
6. SM-210 and SF-190 gave less axial displacement in micro concrete, and ferrocement and CM190 and $\mathrm{CF}-210$ gave less axial displacement in micro concrete and ferrocement.

7. The square and circular RC columns strengthened by Ferrocement mortar did not have any remarkable change exhibited in stress, but axial and lateral strains slightly increased. It leads to failure severely delayed. The square $\&$ circular RC columns were strengthened by micro concrete. The axial and lateral strains' behavior in the micro concrete mortar layer failed immediately after the plastic stage occured. It is noted that drastic changes in axial and lateral strains were observed and increased so that failure occurred would be significantly delayed.

8. The strengthening of micro concrete has also increased nearly one and a half to twice as much axial strain in the reinforcement bar compared to the non-strengthen RC column, which improved the RC column element's overall performance.

9. The ultimate stress carrying capacity of RC columns strengthened by micro concrete is more compared to RC columns strengthened by ferrocement. SM-190 and SM-210 gave more stress carrying capacity in micro concrete square RC columns. In circular RC columns CM-190 and CM-210 gave more stress carrying capacity in micro concrete than ferrocement

10. The experimenta and theoretical ACI-440-2R-08 results are nearest because they consider all properties of materials and specimens. Theoretically, CNR-DT-R1-2013 results were in a large difference because this guideline considers a minimum of materials properties.

11. The cost analysis showed that the strengthening by micro concrete is economical compared to strengthening by Ferrocement.

12. The TOPSIS showed that the strengthening by micro concrete gives better performance compared to strengthening by Ferrocement.

\section{References}

[1] M Kamiński and T Trapko. Experimental behaviour of reinforced concrete column models strengthened by CFRP materials. J. Civ. Eng. Manag. 2006; 12, 109-15.

[2] ABMA Kaish, MR Alam, M Jamil, MFM Zain and MA Wahed. Improved ferrocement jacketing for restrengthening of square RC short column. Constr. Build. Mater. 2012; 36, 228-37.

[3] ABMA Kaish, M Jamil, SN Raman and MFM Zain. Axial behavior of ferrocement confined cylindrical concrete specimens with different sizes. Constr. Build. Mater. 2015; 78, 50-9.

[4] ABMA Kaish, M Jamil, SN Raman, MFM Zain and MR Alam. An approach to improve conventional square ferrocement jacket for strengthening application of short square RC column. Mater. Struct. 2016; 49, 1025-37.

[5] P Rathish Kumar and CBK Rao. Constitutive behaviour of high-performance ferrocement under axial compression. Mag. Concr. Res. 2006; 58, 647-56.

[6] M Soman and J Mohan. Rehabilitation of RC columns using ferrocement jacketing. Constr. Build. Mater. 2018; 181, 156-62.

[7] GJ Xiong, XY Wu, FF Li and Z Yan. Load carrying capacity and ductility of circular concrete columns confined by ferrocement including steel bars. Constr. Build. Mater. 2011; 25, 2263-8.

[8] B Kondraivendhan and B Pradhan. Effect of ferrocement confinement on behavior of concrete. Constr. Build. Mater. 2009; 23, 1218-22.

[9] Abdullah and $\mathrm{K}$ Takiguchi. An investigation into the behavior and strength of reinforced concrete columns strengthened with ferrocement jackets. Cem. Concr. Compos. 2003; 25, 233-42.

[10] K Fukuyama, Y Higashibata and Y Miyauchi. Studies on repair and strengthening methods of damaged reinforced concrete columns. Cem. Concr. Compos. 2000; 22, 81-8.

[11] SM Mourad and MJ Shannag. Repair and strengthening of reinforced concrete square columns using ferrocement jackets. Cem. Concr. Compos. 2012; 34, 288-94.

[12] M Yaqub, CG Bailey, P Nedwell, QUZ Khan and I Javed. Strength and stiffness of post-heated columns repaired with ferrocement and fibre reinforced polymer jackets. Compos. B. Eng. 2013; 44, 200-11.

[13] A Mimiran and M Shahaway. Behavior of concrete column confined by fiber composites B Amir 
http://wjst.wu.ac.th

Mirmiran 1 and Mohsen Shahawy / Members, ASCE, ASCE. J. Struct. Eng. 1997; 123, 583-90.

[14] K Soudki and T Alkhrdaji. Guide for the design and construction of externally bonded FRP systems for strengthening concrete structures (ACI 440.2R-02). In: Proceedings of the 2005 Structures Congress and the 2005 Forensic Engineering Symposium, New York, the United States. 2005, p. 8.

[15] IS 269 - 2015, IS 269 - 2015. Ordinary portland cement - Specification. 2015.

[16] IS 2386 (Part-I)-1963. Methods of test for aggregates for concrete. 2016.

[17] IS 2386 (Part-III)-1963. Methods of test for aggregates for concrete. 2016.

[18] IS 2863 (Part-IV)-1963. Methods of test for aggregates for concrete. 2016.

[19] BIS:10262. Indian standard guidelines for concrete mix design proportioning. Bureau of Indian Standards, New Delhi, 2009.

[20] IS:1786-2008. High strength deformed steel bars and wires for concretereinforcementspecification. Bureau of Indian Standards, New Delhi, 2008, p. 1-12.

[21] ACI Committee 549 1R. Guide for the design, construction, and repair of ferrocement reported. $A C I$ Struct. J. 2009; 85, 325-51.

[22] IS 516-1959. Methods of tests for strength of concrete. 2018.

[23] IS 456. Concrete, plain and reinforced. Bureau of Indian Standards, New Dehli, 2000, p. 1-114.

[24] CNR-DT 200 R1/2013. Guide for the design and construction of externally bonded FRP systems for strengthening existing structures. Consiglio Nazionale delle Ricerche, Italy, 2013.

[25] SR Salla, CD Modhera and UR Babu. An experimental study on various industrial wastes in concrete for sustainable construction. J. Adv. Concr. Technol. 2021; 19, 133-48. 